\title{
Flavisolibacter ginsengiterrae gen. nov., sp. nov. and Flavisolibacter ginsengisoli sp. nov., isolated from ginseng cultivating soil
}

Correspondence

Min-Ho Yoon

mhyoon@cnu.ac.kr

\author{
Min-Ho Yoon ${ }^{1}$ and Wan-Taek $\mathrm{Im}^{2}$
}

\author{
${ }^{1}$ Department of BioEnvironmental Chemistry, College of Agriculture and Life Sciences, Chungnam \\ National University, Gung-dong 22, Yuseong-gu, Daejeon 305-764, Republic of Korea \\ ${ }^{2}$ Department of Biological Sciences, Korea Advanced Institute of Science and Technology, \\ 373-1 Guseong-dong, Yuseong-gu, Daejeon 305-701, Republic of Korea
}

During the course of a study on the culturable bacterial community in soil from a ginseng field in Pocheon Province, South Korea, a large number of novel bacterial strains were isolated (Im et al., 2005). Two of these isolates, Gsoil $492^{\mathrm{T}}$ and Gsoil $643^{\mathrm{T}}$, were members of the phylum Bacteroidetes (Garrity \& Holt, 2001) and were subjected to further taxonomic investigation. On the basis of the results obtained in this study, we propose that strains Gsoil $492^{\mathrm{T}}$ and Gsoil $643^{\mathrm{T}}$ represent members of a novel genus.

Strains Gsoil $492^{\mathrm{T}}$ and Gsoil $643^{\mathrm{T}}$ were isolated from soil from a ginseng field. The soil sample was thoroughly suspended with $50 \mathrm{mM}$ phosphate buffer ( $\mathrm{pH} 7.0$ ) and the suspension was spread on one-fifth-strength modified R2A agar plates (containing, $\mathrm{l}^{-1}, 0.25 \mathrm{~g}$ tryptone, $0.25 \mathrm{~g}$ peptone, $0.25 \mathrm{~g}$ yeast extract, $0.125 \mathrm{~g}$ malt extract, $0.125 \mathrm{~g}$ beef extract, $0.25 \mathrm{~g}$ Casamino acids, $0.25 \mathrm{~g}$ soytone, $0.5 \mathrm{~g}$ glucose, $0.3 \mathrm{~g}$ soluble starch, $0.2 \mathrm{~g}$ xylan, $0.3 \mathrm{~g}$ sodium

The GenBank/EMBL/DDBJ accession numbers for the 16S rRNA gene sequences of strains Gsoil $492^{\top}$ and Gsoil $643^{\top}$ are AB267476 and AB267477, respectively. pyruvate, $0.3 \mathrm{~g} \mathrm{~K}_{2} \mathrm{HPO}_{4}, 0.05 \mathrm{~g} \mathrm{MgSO}_{4}, 0.05 \mathrm{~g} \mathrm{CaCl}_{2}$ and $15 \mathrm{~g}$ agar) after serial dilution with $50 \mathrm{mM}$ phosphate buffer ( $\mathrm{pH}$ 7.0). The plates were incubated at $30{ }^{\circ} \mathrm{C}$ for 1 month. Single colonies on the plates were purified by transferring them onto new plates for incubation on fullstrength modified R2A or one-half-strength modified R2A. As both Gsoil $492^{\mathrm{T}}$ and Gsoil $643^{\mathrm{T}}$ could grow well both on full-strength modified R2A agar and on commercial R2A agar (Difco), they were routinely cultured on the latter medium at $30{ }^{\circ} \mathrm{C}$ and maintained as $\mathrm{R} 2 \mathrm{~A} / 20 \%(\mathrm{w} / \mathrm{v})$ glycerol suspensions at $-70{ }^{\circ} \mathrm{C}$.

The Gram-stain reaction was determined using the nonstaining method, as described by Buck (1982). The cell morphology was observed at $\times 1000$ magnification with a light microscope (Nikon) using cells grown for 3 days at $30{ }^{\circ} \mathrm{C}$ on R2A agar. Catalase activity was determined by assessing bubble production in $3 \%(\mathrm{v} / \mathrm{v}) \mathrm{H}_{2} \mathrm{O}_{2}$, and oxidase activity was determined using $1 \%(\mathrm{w} / \mathrm{v})$ tetramethyl- $p$ phenylenediamine. Carbon-source utilization and enzyme activities were tested by using the API 20NE, API 20E, ID32 GN and API ZYM test kits (bioMérieux). Anaerobic 
growth was tested in serum bottles by adding sodium thioglycolate $\left(1 \mathrm{~g} \mathrm{l}^{-1}\right)$ to $\mathrm{R} 2 \mathrm{~A}$ broth and substituting the upper airspace with nitrogen gas. Tests for the degradation of DNA [performed by flooding DNase agar (Scharlau) plates with $1 \mathrm{M} \mathrm{HCl}$, casein, chitin, starch (Atlas, 1993), lipid (Kouker \& Jaeger, 1987), xylan and cellulose (Ten et al., 2004) were performed and evaluated after 5 days. Growth at different temperatures $(4,15,20,25,30,37$ and $\left.42{ }^{\circ} \mathrm{C}\right)$ and various $\mathrm{pH}$ values $(\mathrm{pH} 5.0-10.0$, in increments of $0.5 \mathrm{pH}$ units) was assessed after 5 days incubation. Salt tolerance was tested on R2A agar supplemented with 1$10 \%(\mathrm{w} / \mathrm{v}) \mathrm{NaCl}$ after 5 days incubation. Growth on nutrient agar, trypticase soy agar (TSA) and MacConkey agar was also evaluated, at $30{ }^{\circ} \mathrm{C}$. Pigment was extracted according to a previously described method (Weeks, 1981), and a spectrum was obtained using a UV-visible spectrophotometer (Beckman). Additionally, the presence of flexirubin-type pigments was tested spectrophotometrically as described previously (Güde, 1980), using $20 \% \mathrm{KOH}$.

Both strains were found to be Gram-negative, aerobic, non-motile, rod-shaped bacteria. Neither strain grew on MacConkey agar or on TSA, whereas both strains could grow on one-tenth-strength TSA. Gsoil $492^{\mathrm{T}}$ was able to grow on nutrient agar, unlike Gsoil $643^{\mathrm{T}}$. On R2A agar medium, strain Gsoil $492^{\mathrm{T}}$ grew at temperatures from 15 to $30{ }^{\circ} \mathrm{C}$ and at $\mathrm{pH}$ values between 6.0 and 8.5 , whereas strain Gsoil $643^{\mathrm{T}}$ grew at temperatures from 15 to $37{ }^{\circ} \mathrm{C}$ and at $\mathrm{pH}$ values between 5.5 and 8.0. For both strains, the optimal temperature and $\mathrm{pH}$ for growth were $30{ }^{\circ} \mathrm{C}$ and $\mathrm{pH}$ 7.0. The $\mathrm{NaCl}$ tolerance range for the growth of Gsoil $492^{\mathrm{T}}$ was $0-3.0 \%(\mathrm{w} / \mathrm{v})$, whereas that for the growth of Gsoil $643^{\mathrm{T}}$ was $0-1.0 \%(\mathrm{w} / \mathrm{v})$. Crude extracts of strains Gsoil $492^{\mathrm{T}}$ and Gsoil $643^{\mathrm{T}}$ showed absorption maxima at approximately 477 and $450 \mathrm{~nm}$, respectively, when extracted in ethanol. A flexirubin-like yellow-coloured pigment was not produced. Other physiological characteristics of strains Gsoil $492^{\mathrm{T}}$ and Gsoil $643^{\mathrm{T}}$ are summarized in the species description. Phenotypic and chemotaxonomic characteristics that serve to differentiate these strains from their closest phylogenetic relatives are listed in Table 1.

To measure the $\mathrm{G}+\mathrm{C}$ content of the chromosomal DNA, genomic DNA from each of the novel strains was extracted and purified as described by Moore \& Dowhan (1995) and was enzymically degraded into nucleosides for analysis by reverse-phased HPLC, as described by Mesbah et al. (1989). Isoprenoid quinones were extracted with chloroform/ methanol $(2: 1, \mathrm{v} / \mathrm{v})$, evaporated under vacuum conditions and then re-extracted in $\mathrm{n}$-hexane/water $(1: 1, \mathrm{v} / \mathrm{v})$. The crude $n$-hexane-quinone solution was purified using Sep-Pak Vac silica cartridges (Waters) and subsequently analysed by HPLC as described previously (Hiraishi et al., 1996). Cellular fatty acid profiles were determined from biomass harvested from one-tenth-strength TSA (Difco) after 3 days incubation. The cellular fatty acids were saponified, methylated and extracted according to the protocol of the Sherlock Microbial Identification System (MIDI). The fatty acids were analysed by using a gas chromatograph (model 6890; Hewlett Packard) and were identified with the Microbial Identification software package (Sasser, 1990). Polyamines were extracted and analysed according to Busse \& Auling (1988) and Schenkel et al. (1995), respectively. DNA-DNA hybridization experiments were performed using the method described by Ezaki et al. (1989) with photobiotin-labelled DNA probes and micro-dilution wells.

The DNA G + C contents of strains Gsoil $492^{\mathrm{T}}$ and Gsoil $643^{\mathrm{T}}$ were 43.0 and $42.7 \mathrm{~mol} \%$, respectively. The major respiratory quinone was MK-7. As shown in Table 2, the major fatty acids in both strains were iso- $\mathrm{C}_{15: 0}$ (31.2$45.9 \%)$, iso- $\mathrm{C}_{17: 0} 3-\mathrm{OH}(11.8-13.7 \%)$ and summed feature $4(6.2-10.5 \%)$. The presence of iso- $\mathrm{C}_{17: 0}$, summed feature 2 and summed feature 5, and some quantitative differences in fatty acid composition, served to distinguish strains Gsoil $492^{\mathrm{T}}$ and Gsoil $643^{\mathrm{T}}$ from other phylogenetically related genera (Table 2 ).

PCR-mediated amplification of the 16S rRNA genes and sequencing of the purified PCR products were carried out according to Kim et al. (2005). Full sequences of the 16S rRNA genes were compiled using SeqMan software (DNASTAR). The 16S rRNA gene sequences of related taxa were obtained from GenBank. Multiple alignments were performed using the CLUSTAL_X program (Thompson et al., 1997). Gaps were edited in the BioEdit program (Hall, 1999). Evolutionary distances were calculated using the Kimura two-parameter model (Kimura, 1983). Phylogenetic trees were constructed by using a neighbourjoining method (Saitou \& Nei, 1987) with the MEGA3 program (Kumar et al., 2004); bootstrap values were based on 1000 replications (Felsenstein, 1985).

Almost-complete 16S rRNA sequences for strains Gsoil $492^{\mathrm{T}}$ and Gsoil $643^{\mathrm{T}}$ were determined and subjected to comparative analysis. A phylogenetic analysis based on $16 \mathrm{~S}$ rRNA gene sequences indicated that the two isolates were clustered with several uncultured bacterial clones and with established genera (Terrimonas, Niastella and Chitinophaga) in the phylum Bacteroidetes but were clearly separated from these genera (Fig. 1). Strains Gsoil $492^{\mathrm{T}}$ and Gsoil $643^{\mathrm{T}}$ showed the highest levels of $16 \mathrm{~S}$ rRNA gene sequence similarity (91.9-92.4\%) with respect to the type strains of the genus Terrimonas, followed by the type strains of Niastella species (91.1-91.8\%) and Chitinophaga species (87.5-89.5\%) with their unique phylogenetic position. The level of $16 \mathrm{~S}$ rRNA gene sequence similarity between the two strains was $99.5 \%$ and the DNA-DNA relatedness value was $44 \%$, which is below the threshold $(70 \%)$ recommended for the assignment of strains to the same bacterial species (Wayne et al., 1987). It is clear from the DNA-DNA relatedness value that strains Gsoil $492^{\mathrm{T}}$ and Gsoil $643^{\mathrm{T}}$ represent two distinct genomic species.

On the basis of the data and observations described above, it is appropriate to conclude that strains Gsoil $492^{\mathrm{T}}$ and Gsoil $643^{\mathrm{T}}$ represent members of a novel genus within the phylum Bacteroidetes, for which the name Flavisolibacter 
Table 1. Phenotypic characteristics of strains Gsoil $492^{\top}$ and Gsoil $643^{\top}$ and related type strains

Strains: 1, Gsoil 492 $2^{\mathrm{T}} ; 2$, Gsoil $643^{\mathrm{T}} ; 3$, Terrimonas lutea $\mathrm{DY}^{\mathrm{T}} ; 4$, Terrimonas ferrruginea ATCC $13524^{\mathrm{T}} ; 5$, Niastella koreensis $\mathrm{GR} 20-10^{\mathrm{T}} ; 6$, Niastella jeongjuensis GR20-13 ${ }^{\mathrm{T}} ; 7$, Chitinophaga japonensis

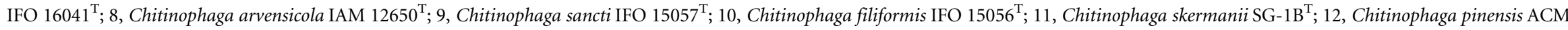
$2034^{\mathrm{T}}$. Data in columns 3-12 are from Xie \& Yokota (2006), Weon et al. (2006) and Kämpfer et al. (2006). None of the strains assimilate inositol. +, Positive; -, negative; w, weak reaction; v, variable among studies; ND, no data available.

\begin{tabular}{|c|c|c|c|c|c|c|c|c|c|c|c|c|}
\hline Characteristic & 1 & 2 & 3 & 4 & 5 & 6 & 7 & 8 & 9 & 10 & 11 & 12 \\
\hline Pigment & Yellow & Yellow & $\begin{array}{l}\text { Red or } \\
\text { yellow }\end{array}$ & $\begin{array}{c}\text { Yellowish } \\
\text { orange }\end{array}$ & $\begin{array}{l}\text { Light } \\
\text { yellow }\end{array}$ & $\begin{array}{l}\text { Milky } \\
\text { white }\end{array}$ & $\begin{array}{l}\text { Yellowish } \\
\text { orange }\end{array}$ & $\begin{array}{c}\text { Yellowish } \\
\text { orange }\end{array}$ & $\begin{array}{l}\text { Golden } \\
\text { yellow }\end{array}$ & $\begin{array}{l}\text { Golden } \\
\text { yellow }\end{array}$ & Yellow & Yellow \\
\hline Cell length $(\mu \mathrm{m})$ & $0.3-1.0$ & $0.3-6.0$ & $1-2$ & $0.6-4.0$ & $10-50$ & $10-40$ & $2-18$ & $0.6-4.0$ & $2-15$ & $30-80$ & $1-2$ & $<40$ \\
\hline Gliding movement & - & - & - & - & + & + & + & - & + & + & - & + \\
\hline Major fatty acids $(>20 \%)$ & iso- $\mathrm{C}_{15: 0}$ & iso- $\mathrm{C}_{15: 0}$ & $\begin{array}{l}\text { iso- } \mathrm{C}_{15: 0} \\
\text { iso- } \mathrm{C}_{15: 1}\end{array}$ & $\begin{array}{l}\text { iso- } C_{15: 0} \\
\text { iso- } C_{15: 1}\end{array}$ & $\begin{array}{c}\text { iso- } \mathrm{C}_{15: 0} \\
\text { iso- } \mathrm{C}_{17: 0} \\
3-\mathrm{OH}\end{array}$ & $\begin{array}{l}\text { iso- } \mathrm{C}_{15: 0} \\
\text { iso- } \mathrm{C}_{17: 0} \\
3-\mathrm{OH}\end{array}$ & $\begin{array}{l}\text { iso- } \mathrm{C}_{15: 0} \\
\mathrm{C}_{16: 1} \omega 5 c\end{array}$ & $\begin{array}{l}\text { iso- } \mathrm{C}_{15: 0} \\
\mathrm{C}_{16: 1} \omega 5 c\end{array}$ & iso- $\mathrm{C}_{15: 0}$ & $\begin{array}{l}\text { iso- } \mathrm{C}_{15: 0} \\
\mathrm{C}_{16: 1} \omega 5 c\end{array}$ & $\begin{array}{l}\text { iso- } \mathrm{C}_{15: 0} \\
\mathrm{C}_{16: 1} \omega 5 c\end{array}$ & $\begin{array}{l}\text { iso- } \mathrm{C}_{15: 0} \\
\mathrm{C}_{16: 1} \omega 5 c\end{array}$ \\
\hline Oxidase & + & - & + & + & - & + & + & + & $\mathrm{ND}$ & + & + & + \\
\hline Catalase & - & + & $\mathrm{w}$ & + & - & - & + & + & - & + & + & - \\
\hline \multicolumn{13}{|l|}{ Hydrolysis of: } \\
\hline Starch & - & - & ND & + & - & - & - & $\mathrm{v}$ & + & - & $\mathrm{ND}$ & - \\
\hline Chitin & - & - & - & - & + & + & - & $\mathrm{ND}$ & - & - & $\mathrm{ND}$ & + \\
\hline Casein & - & - & ND & - & + & + & - & ND & $\mathrm{ND}$ & - & ND & + \\
\hline Gelatin & + & + & + & - & + & + & + & $\mathrm{v}$ & + & $\mathrm{w}$ & + & + \\
\hline Urea & - & - & - & - & - & - & ND & - & $\mathrm{ND}$ & ND & - & + \\
\hline DNA & - & - & $\mathrm{ND}$ & - & - & - & + & + & $\mathrm{ND}$ & + & $\mathrm{ND}$ & - \\
\hline Growth at $37^{\circ} \mathrm{C}$ & - & + & + & + & + & - & + & - & - & + & + & + \\
\hline $\begin{array}{l}\text { Highest } \mathrm{NaCl} \text { conc. }(\%) \text { tolerated } \\
\text { Assimilation of: }\end{array}$ & 3.0 & 1.0 & 1.0 & 1.0 & $\mathrm{ND}$ & $\mathrm{ND}$ & 2.0 & 2.0 & 1.0 & 0.3 & $\mathrm{ND}$ & $\mathrm{ND}$ \\
\hline$N$-Acetyl-D-glucosamine & + & - & + & - & - & - & + & + & - & - & + & + \\
\hline L-Arabinose & + & - & + & - & - & - & + & + & + & - & - & + \\
\hline Gluconate & + & - & - & - & - & - & - & - & + & - & - & - \\
\hline D-Mannose & + & - & + & + & - & - & + & + & + & + & + & + \\
\hline D-Maltose & + & - & + & + & - & - & + & + & + & + & + & + \\
\hline$\alpha$-D-Melibiose & + & - & + & - & - & - & + & + & + & + & + & - \\
\hline L-Rhamnose & + & - & - & + & - & - & + & + & - & - & - & + \\
\hline D-Ribose & - & - & - & - & - & - & - & + & - & - & - & - \\
\hline Sucrose & + & + & + & - & - & - & + & + & - & + & - & + \\
\hline Salicin & + & - & - & - & - & - & + & + & - & + & + & + \\
\hline Nitrate reduction & - & - & - & - & - & - & + & $\mathrm{v}$ & + & + & $\mathrm{ND}$ & - \\
\hline DNA G $+C$ content $(\mathrm{mol} \%)$ & 43.0 & 42.7 & 47.2 & 48.9 & 45.8 & 44.3 & 49.8 & $43-46$ & $46-47$ & $46-47$ & 40.7 & $42-46$ \\
\hline
\end{tabular}


Table 2. Major fatty acids of strains Gsoil $492^{\top}$, Gsoil $643^{\top}$ and related taxa

Strains: 1, Gsoil 492 ${ }^{\mathrm{T}}$; 2, Gsoil $643^{\mathrm{T}} ; 3$, T. lutea DY ${ }^{\mathrm{T}}$; 4, T. ferrruginea ATCC $13524^{\mathrm{T}} ; 5$, N. koreensis GR20-10 ${ }^{\mathrm{T}}$; 6, N. jeongjuensis GR20-13 ${ }^{\mathrm{T}}$; 7, C. japonensis IFO $16041^{\mathrm{T}} ; 8$, C. arvensicola IAM $12650^{\mathrm{T}}$; 9, C. sancti IFO $15057^{\mathrm{T}}$; 10, C. filiformis IFO 15056 ${ }^{\mathrm{T}}$; 11, C. skermanii SG-1B ${ }^{\mathrm{T}}$; 12, C. pinensis ACM 2034 . Data for taxa 3-12 are from Xie \& Yokota (2006), Weon et al. (2006) and Kämpfer et al. (2006). Fatty acids that account for $<1.0 \%$ of the total are not shown. Summed feature 2 comprises any combination of $\mathrm{C}_{12: 0}$ aldehyde, $\mathrm{C}_{14: 0} 3-\mathrm{OH}$ and/or iso- $\mathrm{C}_{16: 1}$; summed feature 3 comprises any combination of iso- $\mathrm{C}_{15: 0} 2-\mathrm{OH}$ and/or $\mathrm{C}_{16: 1} \omega 7 c$; summed feature 4 comprises any combination of iso- $\mathrm{C}_{17: 1} \mathrm{I}$ and/or anteiso- $\mathrm{C}_{17: 1}$ $\mathrm{B}$; summed feature 5 comprises iso- $\mathrm{C}_{17: 1} \mathrm{I}$ and/or anteiso- $\mathrm{C}_{17: 1} \mathrm{~B}$; summed feature 6 comprises $\mathrm{C}_{18: 2} \omega 6,9 c$ and/or anteiso- $\mathrm{C}_{18: 0}$; summed feature 7 comprises $\mathrm{C}_{18: 1} \omega 7 c, \mathrm{C}_{18: 1} \omega 9 t$ or $\mathrm{C}_{18: 1} \omega 12 t$ or any combination of these isomers. -, Not detected.

\begin{tabular}{|c|c|c|c|c|c|c|c|c|c|c|c|c|}
\hline Fatty acid & 1 & 2 & 3 & 4 & 5 & 6 & 7 & 8 & 9 & 10 & 11 & 12 \\
\hline iso- $\mathrm{C}_{14: 0}$ & - & - & 4.3 & 1.1 & - & - & - & - & - & - & - & - \\
\hline $\mathrm{C}_{14: 0}$ & - & - & - & - & - & - & - & 1.4 & - & - & 1.8 & - \\
\hline iso- $\mathrm{C}_{15: 0}$ & 45.9 & 31.2 & 34.8 & 28.4 & 26.8 & 30.6 & 40.0 & 35.3 & 44.0 & 37.3 & 47.3 & 30.4 \\
\hline anteiso- $\mathrm{C}_{15: 0}$ & 5.9 & 5.0 & - & - & 4.9 & 3.3 & - & - & - & - & - & - \\
\hline iso- $\mathrm{C}_{15: 1}$ & 5.3 & 4.4 & 21.8 & 26.2 & 15.6 & 14.7 & - & - & - & - & - & - \\
\hline iso- $\mathrm{C}_{17: 1} \omega 9 c$ & 1.3 & - & - & - & - & - & - & - & 1.1 & - & - & - \\
\hline $\mathrm{C}_{16: 1} \omega 11 c$ & - & - & - & - & - & - & 1.0 & - & - & - & - & 1.9 \\
\hline $\mathrm{C}_{16: 1} \omega 5 c$ & - & - & - & - & - & 1.2 & 22.2 & 33.6 & 13.5 & 25.5 & 24.4 & 33.2 \\
\hline $\mathrm{C}_{16: 0} 2-\mathrm{OH}$ & - & - & - & - & - & - & 3.0 & - & - & 1.1 & - & - \\
\hline$C_{16: 0}$ & 5.5 & 7.5 & 1.1 & 1.7 & 2.6 & 2.9 & 3.0 & 5.1 & 4.2 & 4.3 & 3.5 & 4.2 \\
\hline iso- $\mathrm{C}_{16: 0}$ & - & - & - & 1.4 & 1.0 & - & - & 0.3 & - & - & - & - \\
\hline anteiso- $\mathrm{C}_{17: 0}$ & - & 1.0 & - & - & - & - & - & - & - & - & - & - \\
\hline $\mathrm{C}_{17: 0} 2-\mathrm{OH}$ & - & - & - & - & 3.5 & 2.6 & - & - & - & - & - & - \\
\hline $\mathrm{C}_{17: 0} 3-\mathrm{OH}$ & - & - & - & - & 1.2 & - & - & - & - & - & - & - \\
\hline iso- $\mathrm{C}_{17: 0} 3-\mathrm{OH}$ & 13.7 & 11.8 & 14.2 & 15.3 & 29.4 & 27.1 & 13.0 & 5.9 & 9.1 & 11.8 & 5.0 & 11.5 \\
\hline $\mathrm{C}_{18: 0}$ & - & 2.0 & - & - & - & - & - & - & - & - & - & - \\
\hline Unknown & - & - & - & - & - & - & - & - & - & - & - & - \\
\hline $\begin{array}{l}\text { Equivalent chain- } \\
\text { length } 13.565\end{array}$ & - & - & 3.2 & 1.3 & - & - & 3.1 & 3.6 & 3.2 & 2.5 & 4.4 & 2.6 \\
\hline $\begin{array}{l}\text { Equivalent chain- } \\
\text { length } 16.582\end{array}$ & - & - & 1.8 & 1.3 & 1.4 & 1.6 & 1.1 & - & 1.3 & 0.9 & - & 1.1 \\
\hline \multicolumn{13}{|l|}{ Summed features } \\
\hline
\end{tabular}

nov. is proposed. Strains Gsoil $492^{\mathrm{T}}$ and Gsoil $643^{\mathrm{T}}$ should be classified within this genus as Flavisolibacter ginsengiterrae sp. nov. and Flavisolibacter ginsengisoli sp. nov., respectively.

\section{Description of Flavisolibacter gen. nov.}

Flavisolibacter (Fla.vi.so.li.bac'ter. L. adj. flavus yellow; L. n. solum soil; N.L. masc. n. bacter a rod; N.L. masc. n. Flavisolibacter a yellow, rod-shaped bacterium from soil).

Gram-negative, aerobic, non-motile and chemoheterotrophic. Nitrate is not reduced under aerobic conditions.
The major fatty acids are iso- $\mathrm{C}_{15: 0}$ and iso- $\mathrm{C}_{17: 0} 3-\mathrm{OH}$. The major respiratory quinone is MK-7. Homospermidine is the major polyamine component. Positioned phylogenetically within the phylum Bacteroidetes. The type species is Flavisolibacter ginsengiterrae.

\section{Description of Flavisolibacter ginsengiterrae sp. nov.}

Flavisolibacter ginsengiterrae (gin.sen.gi.te.r'rae. N.L. n. ginsengum ginseng; L. n. terra soil; N.L. gen. n. ginsengiterrae of soil from a ginseng field). 


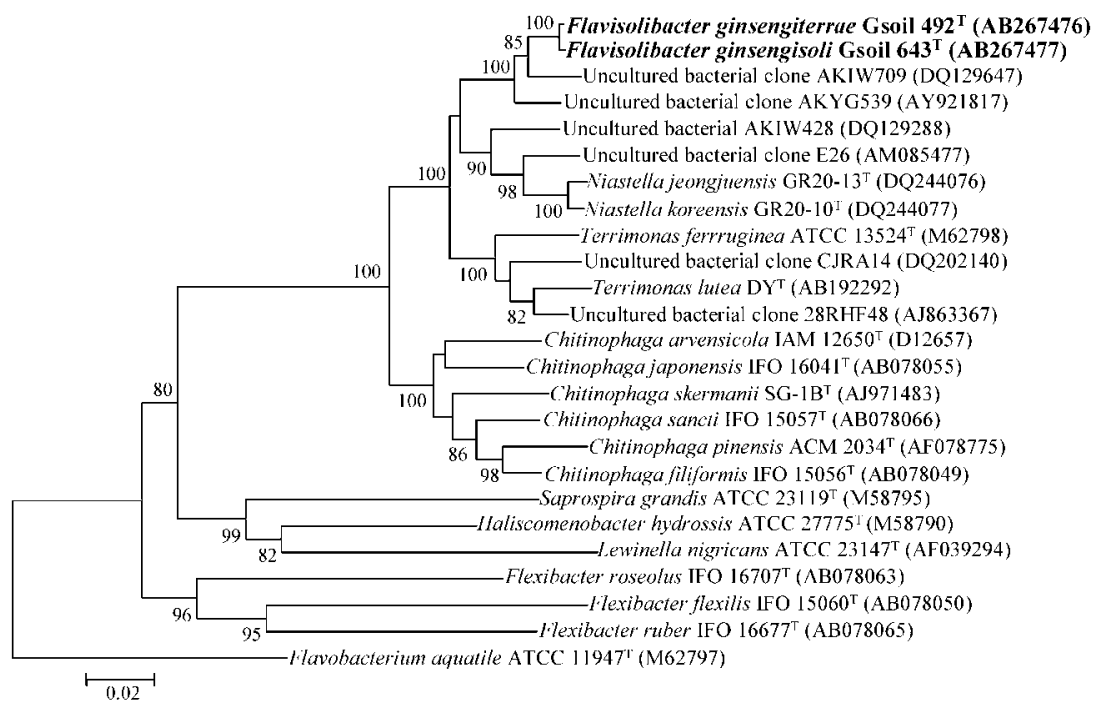

Fig. 1. Rooted phylogenetic tree based on the 16S rRNA gene sequences of strains Gsoil $492^{\top}$ and Gsoil $643^{\top}$ and related bacteria in the phylum Bacteroidetes. This tree was constructed using the neighbour-joining method (Saitou \& Nei, 1987) with a twoparameter Kimura (1983) distance matrix and pairwise deletion. Bootstrap percentages (from 1000 replications) greater than 70\% are shown at the branch points. Bar, 20 nucleotide substitutions per 1000 nucleotides.
Possesses the following properties in addition to those given in the genus description. Cells are $0.3-0.7 \times 0.6-$ $1.0 \mu \mathrm{m}$. Colonies grown on R2A agar plates are smooth, circular, convex, opaque and yellow in colour within 5 days at $30{ }^{\circ} \mathrm{C}$. Optimal growth temperature and $\mathrm{pH}$ are $30{ }^{\circ} \mathrm{C}$ and $\mathrm{pH}$ 7.0. $\mathrm{N}$-acetyl-D-glucosamine, L-arabinose, Lfucose, glycogen, glucose, histidine, maltose, D-mannose, D-melibiose, L-proline, rhamnose, salicin and D-sucrose are assimilated. Positive for hydrolysis of aesculin and gelatin and for $\beta$-galactosidase activity. Negative reactions are observed for hydrolysis of urea, indole production, glucose fermentation, arginine dihydrolase, $\mathrm{H}_{2} \mathrm{~S}$ production and assimilation of acetate, adipate, L-alanine, n-caprate, citrate, gluconate, 3-hydroxybenzoate, 4-hydroxybenzoate, 3-hydroxybutyrate, inositol, itaconate, 2-ketogluconate, 5ketogluconate, lactate, DL-malic acid, malonate, mannitol, phenylacetate, propionate, D-ribose, L-serine, D-sorbitol, suberate and valerate. With the API ZYM gallery, positive for $N$-acetyl- $\beta$-glucosaminidase, acid phosphatase, alkaline phosphatase, $\alpha$-chymotrypsin, cystine arylamidase, esterase (C4), esterase lipase (C8), $\alpha$-galactosidase, $\beta$-galactosidase, $\beta$-glucosidase, leucine arylamidase and valine arylamidase, and weakly positive for $\alpha$-fucosidase. Negative for $\alpha$ glucosidase, $\beta$-glucuronidase, lipase (C14), $\alpha$-mannosidase, naphthol-AS-BI-phosphohydrolase and trypsin. The DNA $\mathrm{G}+\mathrm{C}$ content is $43.0 \mathrm{~mol} \%$.

The type strain, Gsoil $492^{\mathrm{T}} \quad\left(=\mathrm{KCTC} 12656^{\mathrm{T}}=\mathrm{DSM}\right.$ $\left.18136^{\mathrm{T}}\right)$, was isolated from soil from a ginseng field in Pocheon Province, South Korea.

\section{Description of Flavisolibacter ginsengisoli sp. nov.}

Flavisolibacter ginsengisoli (gin.sen.gi.so'li. N.L. n. ginsengum ginseng; L. n. solum soil; N.L. gen. n. ginsengisoli of soil from a ginseng field).
Possesses the following properties in addition to those given in the genus description. Cells are $0.3-0.7 \times 3.0-$ $6.0 \mu \mathrm{m}$. Colonies grown on R2A agar plates are circular, convex, opaque and yellow. Optimal growth temperature and $\mathrm{pH}$ are $30{ }^{\circ} \mathrm{C}$ and $\mathrm{pH}$ 7.0. 3-Hydroxybenzoate, Lfucose, 5-ketogluconate, mannitol, L-proline and D-sucrose are assimilated. Positive for hydrolysis of aesculin and for $\beta$-galactosidase activity. Negative reactions are observed for hydrolysis of urea and gelatin, indole production, glucose fermentation, arginine dihydrolase, $\mathrm{H}_{2} \mathrm{~S}$ production and assimilation of acetate, $\mathrm{N}$-acetyl-D-glucosamine, adipate, L-alanine, L-arabinose, n-caprate, citrate, gluconate, glucose, glycogen, histidine, 4-hydroxybenzoate, 3-hydroxybutyrate, inositol, itaconate, 2-ketogluconate, lactate, DL-malic acid, malonate, maltose, D-mannose, Dmelibiose, phenylacetate, propionate, rhamnose, D-ribose, salicin, L-serine, D-sorbitol, suberate and valerate. With the API ZYM gallery, positive for $N$-acetyl- $\beta$-glucosaminidase, acid phosphatase, alkaline phosphatase, $\alpha$-chymotrypsin, cystine arylamidase, esterase (C4), esterase lipase (C8), $\alpha$-galactosidase, $\alpha$-glucosidase, $\beta$-glucosidase, leucine arylamidase and valine arylamidase, and weakly positive for $\alpha$-fucosidase. Negative for $\beta$-galactosidase, $\beta$-glucuronidase, lipase (C14), $\alpha$-mannosidase, naphthol-AS-BI-phosphohydrolase and trypsin. The DNA $\mathrm{G}+\mathrm{C}$ content is $42.7 \mathrm{~mol} \%$.

The type strain, Gsoil $643^{\mathrm{T}} \quad\left(=\right.$ KCTC $12657^{\mathrm{T}}=\mathrm{DSM}$ $18119^{\mathrm{T}}$ ), was isolated from soil from a ginseng field in Pocheon Province, South Korea.

\section{Acknowledgements}

This work was supported by a grant from the Korea Science and Engineering Foundation, Ministry of Science and Technology, Republic of Korea. We thank Jean Euzéby for his help with the etymology of the species epithet. 


\section{References}

Atlas, R. M. (1993). Handbook of Microbiological Media. Edited by L. C. Parks. Boca Raton, FL: CRC Press.

Buck, J. D. (1982). Nonstaining $(\mathrm{KOH})$ method for determination of Gram reactions of marine bacteria. Appl Environ Microbiol 44, 992-993.

Busse, H.-J. \& Auling, G. (1988). Polyamine pattern as a chemotaxonomic marker within the Proteobacteria. Syst Appl Microbiol 11, $1-8$.

Ezaki, T., Hashimoto, Y. \& Yabuuchi, E. (1989). Fluorometric deoxyribonucleic acid-deoxyribonucleic acid hybridization in microdilution wells as an alternative to membrane filter hybridization in which radioisotopes are used to determine genetic relatedness among bacterial strains. Int J Syst Bacteriol 39, 224-229.

Felsenstein, J. (1985). Confidence limits on phylogenies: an approach using the bootstrap. Evolution 39, 783-791.

Garrity, G. M. \& Holt, J. G. (2001). The road map to the Manual. In Bergey's Manual of Systematic Bacteriology, 2nd edn, vol. 1, pp. 119-166. Edited by D. R. Boone, R. W. Castenholz \& G. M. Garrity. New York: Springer.

Güde, H. (1980). Occurrence of cytophagas in sewage plants. Appl Environ Microbiol 39, 756-763.

Hall, T. A. (1999). BioEdit: a user-friendly biological sequence alignment editor and analysis program for Windows 95/98/NT. Nucleic Acids Symp Ser 41, 95-98.

Hiraishi, A., Ueda, Y., Ishihara, J. \& Mori, T. (1996). Comparative lipoquinone analysis of influent sewage and activated sludge by highperformance liquid chromatography and photodiode array detection. J Gen Appl Microbiol 42, 457-469.

Im, W.-T., Jung, H.-M., Cui, Y.-S., Liu, Q.-M., Zhang, S.-L. \& Lee, S.-T. (2005). Cultivation of the three hundreds of bacterial species from soil of a ginseng field and mining the novel lineage bacteria. In Proceedings of the International Meeting of the Federation of Korean Microbiological Societies, abstract A035, p. 169. Seoul: Federation of Korean Microbiological Societies.

Kämpfer, P., Young, C. C., Sridhar, K. R., Arun, A. B., Lai, W. A. Shen, F. T. \& Rekha, P. D. (2006). Transfer of [Flexibacter] sancti, [Flexibacter] filiformis, [Flexibacter] japonensis, and [Cytophaga] avensicola to the genus Chitinophaga and description of Chitinophaga skermanii sp. nov. Int J Syst Evol Microbiol 56, 2223-2228.

Kim, M. K., Im, W.-T., Ohta, H., Lee, M. \& Lee, S.-T. (2005). Sphingopyxis granuli sp. nov., a $\beta$-glucosidase producing bacterium in the family Sphingomonadaceae in $\alpha-4$ subclass of the Proteobacteria. J Microbiol 43, 152-157.

Kimura, M. (1983). The Neutral Theory of Molecular Evolution. Cambridge: Cambridge University Press.

Kouker, G. \& Jaeger, K.-E. (1987). Specific and sensitive plate assay for bacterial lipase. Appl Environ Microbiol 53, 211-213.
Kumar, S., Tamura, K. \& Nei, M. (2004). MEGA3: integrated software for molecular evolutionary genetics analysis and sequence alignment. Brief Bioinform 5, 150-163.

Mesbah, M., Premachandran, U. \& Whitman, W. B. (1989). Precise measurement of the $\mathrm{G}+\mathrm{C}$ content of deoxyribonucleic acid by high-performance liquid chromatography. Int J Syst Bacteriol 39, 159-167.

Moore, D. D. \& Dowhan, D. (1995). Preparation and analysis of DNA. In Current Protocols in Molecular Biology, pp. 2-11. Edited by F. M. Ausubel, R. Brent, R. E. Kingston, D. D. Moore, J. G. Seidman, J. A. Smith \& K. Struhl. New York: Wiley.

Saitou, N. \& Nei, M. (1987). The neighbor-joining method: a new method for reconstructing phylogenetic trees. Mol Biol Evol 4, 406-425.

Sasser, M. (1990). Identification of bacteria by gas chromatography of cellular fatty acids, MIDI Technical Note 101. Newark, DE: MIDI Inc.

Schenkel, E., Berlaimont, V., Dubois, J., Helson-Cambier, M. \& Hanocq, M. (1995). Improved high-performance liquid chromatographic method for the determination of polyamines as their benzoylated derivatives: application to P388 cancer cells. J Chromatogr B Biomed Appl 668, 189-197.

Ten, L. N., Im, W.-T., Kim, M.-K., Kang, M.-S. \& Lee, S.-T. (2004). Development of a plate technique for screening of polysaccharidedegrading microorganisms by using a mixture of insoluble chromogenic substrates. J Microbiol Methods 56, 375-382.

Thompson, J. D., Gibson, T. J., Plewniak, F., Jeanmougin, F. \& Higgins, D. G. (1997). The CLUSTAL_X windows interface: flexible strategies for multiple sequence alignment aided by quality analysis tools. Nucleic Acids Res 25, 4876-4882.

Wayne, L. G., Brenner, D. J., Colwell, R. R., Grimont, P. A. D., Kandler, O., Krichevsky, M. I., Moore, L. H., Moore, W. E. C., Murray, R. G. E. \& other authors (1987). International Committee on Systematic Bacteriology. Report of the ad hoc committee on reconciliation of approaches to bacterial systematics. Int J Syst Bacteriol 37, 463-464.

Weeks, O. B. (1981). Preliminary studies of the pigments of Flavobacterium breve NCTC 11099 and Flavobacterium odoratum NCTC 11036. In The Flavobacterium-Cytophaga Group, pp. 108-114. Edited by $\mathrm{H}$. Reichenbach \& O. B. Weeks. Weinheim: Gesellschaft für Biotechnologische Forschung.

Weon, H.-Y., Kim, B.-Y., Yoo, S.-H., Lee, S.-Y., Kwon, S.-W., Go, S.-J. \& Stakebrandt, E. (2006). Niastella koreensis gen. nov., sp. nov. and Niastella yeongjuensis sp. nov., novel members of the phylum Bacteroidetes, isolated from soil cultivated with Korean ginseng. Int J Syst Evol Microbiol 56, 1777-1782.

Xie, C.-H. \& Yokota, A. (2006). Reclassification of [Flavobacterium] ferrugineum as Terrimonas ferruginea gen. nov., comb. nov., and description of Terrimonas lutea sp. nov., isolated from soil. Int J Syst Evol Microbiol 56, 1117-1121. 